\title{
Geography of Human Capital in Republic of Kazakhstan: a Comparison Between Regions
}

\author{
Gulnara N. Nyussupova ${ }^{1 *}$, Gaukhar B. Aidarkhanova ${ }^{1}$, Aigul A. Tokbergenova ${ }^{1}$ \\ ${ }^{1}$ Al-Farabi Kazakh National University, 71 al-Farabi Ave., 050040, Almaty, Kazakhstan
}

\begin{abstract}
In the context of the transition of the national economy of the Republic of Kazakhstan to an innovative type of development, the issues of formation and development of human capital are becoming increasingly important. This research is devoted to assessing the regional differentiation of human capital in Kazakhstan and identifying the reasons that shape it. On the basis of factor analysis, a system of statistical indicators of human capital development level was developed. Because human capital is formed throughout the life of the population, the study was carried out according to the stages of accumulation, formation, and use of this capital. This article provides an assessment of human capital main indicators in the regions for 2010-2020. A method for measuring human capital based on quantitative and qualitative indicators of human development using the index method is proposed. The methodology includes economic, social, demographic, and environmental indicators of human capital. An integral index of the human capital of Kazakhstan's regions has been developed, which includes four components and allows one to compare the level of human capital in regions of Kazakhstan. The typology of regions according to the level of human capital development is presented. A geodatabase of regions' human capital has been created. The integral index of the human capital of Kazakhstan's regions allows identifying territorial disproportions. Based on the results of the research, conclusions were drawn about the relationship between the level of human capital development and the level of socio-economic development of the Kazakhstan regions.
\end{abstract}

Keywords: human capital, index approach, regions, spatial differentiation, indicators

For citation: Nyussupova, G.N., Aidarkhanova, G.B., \& Tokbergenova A.A. 2021). Geography of Human Capital in Republic of Kazakhstan: a Comparison Between Regions. Economics: the Strategy and Practice, 16(4), 160-173, https://doi.org/10.51176/1997-9967-2021-4 -160-173

* Corresponding author: Nyussupova G.N. - Doctor of Geographic Sciences, professor, Head of the Department of Geography, Land Management and Cadastre, Al-Farabi Kazakh National University, 71 al-Farabi Ave., 050040, Almaty, Kazakhstan, 87013492053, e-mail: gulnara.nyusupova@kaznu.kz

Conflict of interests: the authors declare that there is no conflict of interest

Financial support. This research has been/was/is funded by the Science Committee of the Ministry of Education and Science of the Republic of Kazakhstan (Grant No. BR10965247 "Study of factors, characteristics and dynamics of demographic processes, migration, urbanization in Kazakhstan, development of digital maps and forecasts")

The article received: 30.11 .2021

The article approved for publication: 21.12 .2021

Date of publication: 30.12 .2021 


\title{
Қазақстан Республикасындағы адам капиталының географиясы: аймақтар арасындағы салыстыру
}

\author{
Нүсіпова Г.Н. ${ }^{\text {* }}$, Айдарханова Г.Б. ${ }^{1}$, Тоқбергенова А.А. ${ }^{1}$ \\ ${ }^{l}$ әл-Фараби атындавы Қазақ Ұлттық университеті, әл-Фараби даңъ., 71, 050040, Алматы,, \\ Қазақ̆стан
}

\begin{abstract}
Түйін
Қазақстан Республикасының ұлттық экономикасының дамудың инновациялық түріне көшу жағдайында адами капиталды қалыптастыру және дамыту мәселелерінің өзектілігі арта түсуде. Қазіргі уақытта адам капиталы аймақтар мен республиканың дамуының негізгі факторларының бірі болып табылады. Дегенмен, Қазақстан Республикасының аумағы бойынша адам капиталының таралуы өте әркелкі және тұрақты өзгерістерге ұшырайды. Бұл зерттеу Қазақстан Республикасындағы адами капиталдың деңгейінің аймақтық саралануын бағалауға және қалыптасқан жағдайдың себептерін анықтауға бағытталған. Зерттеу аясында факторлық талдау негізінде Қазақстан Республикасының аймақтарындағы адами капиталдың даму деңгейінің статистикалық көрсеткіштерінің жүйесі әзірленді. Адами капитал адамның даму процесінде өмір бойы қалыптасатынын ескере отырып, капиталдың осы түрін жинақтау, қалыптастыру және пайдалану кезеңдері бойынша зерттеу жүргізілді. Бұл мақалада 2010-2020 жылдарға арналған динамикадағы Қазақстан Республикасы өңірлерінің адами капиталының негізгі көрсеткіштеріне баға берілген. Мақалада Қазақстан Республикасы аймақтарындағы адами капиталдың даму деңгейін бағалау әдістемесі берілген. Индекс әдісін қолдану арқылы адам дамуының сандық және сапалық көрсеткіштеріне негізделген адами капиталды өлшеу әдісі ұсынылған. Әдістеме адами капиталдың экономикалық, әлеуметтік, демографиялық және экологиялық индикаторларды қамтиды. Қазақстан Республикасы аймақтарының адами капиталының интегралды индексі әзірленді, ол барлық 4 құрамдас бөліктерін қамтиды және Қазақстан Республикасының өңірлеріндегі жинақталған адами капитал деңгейін салыстыруға мүмкіндік береді. Адами капиталдың даму деңгейі бойынша республика аймақтарының типологиясы берілген. Қазақстан Республикасы өңірлерінің адами капиталының геодеректер базасы құрылды, оған демографиялық, әлеуметтік-экономикалық және экологиялық көрсеткіштер кіреді. Өңірлердің адами капиталының интегралды бағалауы бойынша жүргізілген есептеулер аумақтық диспропорцияларды анықтауға және адами капитал даму деңгейі бойынша өңірлерді шартты түрде бөліп көрсетуге мүмкіндік берді. Зерттеу нәтижелері бойынша адами капиталдың даму деңгейі мен Қазақстан Республикасы аймақтарының әлеуметтікэкономикалық даму деңгейі арасындағы байланыс туралы қорытындылар жасалды.
\end{abstract}

Түйін сөздер: адами капитал, индекстік тәсіл, өңірлер, кеңістіктік саралау, индикаторлар

Дәйексөз алу үшін: Нүсіпова Г.Н., Айдарханова Г.Б., Тоқбергенова А.А. (2021). Қазақстан Республикасындағы адам капиталының географиясы: аймақтар арасындағы салыстыру. Экономика: стратегия және практика, 16(4), 160-173, https://doi.org/10.51176/1997-9967-2021-4 -160-173

* Хат-хабаршы авторы: Нүсіпова Г.Н. - г.ғ.д., профессор, география, жерге орналастыру және кадастр кафедрасының меңгерушсі, әл-Фараби атындағы Қазақ Ұлттық университеті, әл-Фараби даңғылы, 71, 050040, Алматы, Қазақстан, 87013492053, e-mail: gulnara.nyusupova@kaznu.kz

Мүдделер қақтығысы: авторлар мүдделер қақтығысының жоқтығын мәлімдейді.

Қаржыландыру. Мақала BR10965247 «Қазақстандағы демографиялық процестердің, көші-қон, урбанизация ерекшеліктері мен динамикасын, факторларын зерттеу, цифрлық карталар мен болжамдарды әзірлеу» бағдарламасы аясында дайындалған. Қаржыландыру көзі - Қазақстан Республикасы Білім және ғылым министрлігінің Ғылым комитеті

Мақала редакцияға түсті: 30.11 .2021

Жариялау туралы шешім қабылданды: 21.12.2021

Жарияланды: 30.12 .2021 


\title{
География человеческого капитала в Республике Казахстан: сравнение регионов
}

\author{
Нюсупова Г.Н. ${ }^{1 *}$, Айдарханова Г.Б. ${ }^{1}$, Токбергенова А.А. ${ }^{1}$ \\ ${ }^{1}$ Казахский национальный университет им. аль-Фараби, пр. аль-Фараби, 71, 050040, г. Алматы, \\ Казахстан
}

\begin{abstract}
Аннотация
В условиях перехода национальной экономики Республики Казахстан на инновационный тип развития, вопросы формирования и развития человеческого капитала приобретают все большую актуальность. В настоящее время человеческий капитал выступает одним из ключевых факторов развития регионов и республики. Однако распределение человеческого капитала по территории Республики Казахстан крайне неоднородно и подвержено постоянным изменениям. Данное исследование посвящено оценке региональной дифференциации человеческого капитала в Республике Казахстан и выявлению причин, формирующих его. В рамках исследования на основе факторного анализа была разработана система статистических показателей уровня развития человеческого капитала регионов Казахстана. Учитывая то, что человеческий капитал формируется на протяжении жизнедеятельности населения, исследование проводилось согласно этапам накопления, формирования и применения этого капитала. В данной статье дана оценка основным индикаторам человеческого капитала в динамике за 2010-2020 гг. по регионам Казахстана. Представлена методика оценки уровня развития человеческого капитала регионов Республики Казахстан. Предлагаемая методика измерения человеческого капитала основана на количественных и качественных индикаторах человеческого развития с использованием индексного метода. В методику включены экономические, социальные, демографические и экологические индикаторы человеческого капитала. Разработан интегральный индекс человеческого капитала регионов, включающий четыре составляющих компонента и позволяющий сравнить уровень развития человеческого капитала в регионах Казахстана. Представлена типология регионов республики по уровню развития человеческого капитала на основе интегральных индексов человеческого капитала. Создана база геоданных человеческого капитала регионов Казахстана, включающая в себя демографические, социально - экономические и экологические индикаторы. Сделанные расчеты, по интегральной оценке, человеческого капитала регионов позволили выявить территориальные диспропорции и условно выделить регионы по уровню развития человеческого капитала. По результатам исследования сделаны выводы о связи уровня развития человеческого капитала с уровнем социально-экономического развития регионов Республики Казахстан.
\end{abstract}

Ключевые слова: человеческий капитал, индексный подход, регионы, пространственная дифференциация, индикаторы

Для цитирования: Нюсупова Г.Н., Айдарханова Г.Б., Токбергенова А.А. (2021). География человеческого капитала в Республике Казахстан: сравнение регионов. Экономика: стратегия и практика, 16(4), 160-173, https://doi.org/10.51176/1997-9967-2021-4-160-173

* Корреспондирующий автор: Нюсупова Г.Н. - д. г. Н., профессор, заведующая кафедрой географии, землеустройства и кадастра, Казахский национальный университет им. аль-Фараби, 050040, г. Алматы, пр. аль-Фараби, 71, Казахстан, 87013492053, e-mail: gulnara.nyusupova@kaznu.kz

Конфликт интересов: авторы заявляют об отсутствии конфликта интересов.

Финансирование. Статья подготовлена в рамках программы BR10965247 «Исследование факторов, особенностей и динамики демографических процессов, миграции, урбанизации в Казахстане, разработка цифровых карт и прогнозов». Источник финансирования - Комитет науки Министерства образования и науки Республики Казахстан.

Статья поступила в редакцию: 30.11 .2021

Принято решение о публикации: 21.12 .2021

Опубликовано: 30.12 .2021 


\section{Kipicne}

Кез келген қоғамның дамуындағы негізгі сілтемесі адам факторының, адам ресурсының, адам капиталының құндылығы болып табылады. Әлемдік ғылыми-техникалық және әлеуметтік-экономикалық дамудың қазіргі кезеңі экономика мен қоғамдағы адам факторының рөлі мен маңыздылығының түбегейлі өзгеруімен сипатталады. Адами капитал экономикалық өсудің аса маңызды факторына айналып, елдің болашағын айқындайды.

Әлемде мемлекеттің адами капиталды арттыруға арналған шығыстары бұрыннан бері әлеуметтік шығындар ретінде қарастырылмайды, бұл - табыс әкелетін инвестициялар. Жаһандық бәсекелестікте өздерінің білім беру әлеуетін жүйелі түрде алға дамытып отыратын елдер жеңіске жетеді.

Тәуелсіздік жылдарында Қазақстан Республикасында адам капиталын арттыру және халықтың өмір сүру сапасын жақсарту үшін барлық қажетті база құрылды [1]. Бұл ретте Қазақстан Республикасының өңірлеріндегі әлеуметтік-экономикалық, демографиялық ахуал, өмір салты бірдей емес, демек, адами капиталдың даму деңгейі ел аумағы бойынша сараланған. Яғни, Қазақстанның кейбір өңірлерін даму деңгейі бойынша дамыған елдермен, ал қалған өңірлерін әлемнің дамушы елдерімен салыстыруға болады. Қазақстан Республикасы барлық өңірлерде халықтың өмір сүру деңгейін жақсартуға ұмтылады, яғни жағдайларды теңестіруге және олардың даму деңгейін арттыруға бағытталған өңірлік саясатты жүргізеді.

Осы зерттеу Қазақстан Республикасында адами капиталдың даму деңгейін өңірлік саралауды бағалау және қалыптасқан жағдайдың себептерін анықтау үшін адами капиталдың дамуын сипаттайтын негізгі индикаторларды зерделеуге бағытталған. Мақалада әртүрлі өлшем бірліктерінде көрсетілген әр түрлі индикативті көрсеткіштерді салыстырмалы түрге айналдыруға мүмкіндік беретін адами капиталды бағалаудың табиғи немесе индекстік әдісіне негізделген әдіс ұсынылған.

\section{Әдеби шолу}

«Адами капитал» санаты, адами капиталды дамыту мәселелері мен мәселелері жақын және алыс шетелдердің классиктерінің де, қазіргі заманғы ғалымдарының да еңбектерінде көрініс тапты. Ағылшын экономисті, ағылшын классикалық экономикалық ойының негізін қалаушы У. Петти бірінші болып адам капиталын сандық өлшеуге мүмкіндік жасауға тырысты. Ол адами капитал деп - адамның өзін және оның пайдалы қасиеттері деп атады. Мектептерге, университеттерге шығындар, дарынды және талантты адамдарды қолдау, сондай-ақ мұқтаждарға, жетім балаларға көмек көрсету Петти мемлекеттік бюджет шығыстарының маңызды бөлігі деп есептеді $[2,54$ б]. Адам капиталының теориялық моделін Г.Беккер әзірледі, ол адам капиталы бұл әркімнің білімі, дағдылары мен уәждерінің қоры деп есептеді. «Бұл инвестициялар біліктілікті, білімді немесе денсаулықты жақсартады, сондықтан ақшалай немесе заттай кірістердің өсуіне ықпал етеді» [3, 87 б]. Нобель сыйлығының лауреаты С. Кузнец адам капиталы дамушы елдер экономикаларының ықтимал тұрақты өсуінің басты доминанты деп санайды [4]. Адами капиталды тәуелсіз экономикалық талдау институтына ұсыну американдық экономист, Нобель сыйлығының лауреаты Т. Шульцке тиесілі [5]. Адам капиталы теориясының одан әрі дамуына мүмкіндік берген американдық ғалым С.Фишер келесі анықтаманы ұсынды: «Адам капиталы-бұл адамның табыс табу қабілетін жүзеге асырудың өлшемі. Адам капиталы туа біткен қабілеттер мен таланттарды, сондай-ақ білім мен біліктілікке ие» [6, 23 б.]. Jong-Suk Han, Jong-Wha Lee [7, 2 б.] адам капиталын жұмыс күшінің құрамы бойынша жасына, жынысына, біліміне және жалақы деңгейіне қарай бағалады.

Ресей ғалымдары арасында Адами капитал феномені белсенді талқыланды. С. А. Дятлов адам капиталын инвестициялар нәтижесінде қалыптасқан және адам жинақтаған денсаулық, білім, дағды, қабілет, мотивация қоры ретінде түсіндірді, оны әлеуметтік көбеюдің белгілі бір саласында қолданған жөн, еңбек өнімділігі мен өндіріс тиімділігінің өсуіне ықпал етеді, сол арқылы адамның, фирманың және бүкіл қоғамның табысының өсуіне әсер етеді [8]. Сонымен қатар, кейбір ғалымдар адам капиталы жалпы капиталдың бір бөлігі бола отырып, жалпы білім беру, арнайы оқыту, денсаулық сақтау, жұмыс күші қозғалысының жинақталған шығындарын білдіретінін қосады [9-10]. Р.И.Капелюшников адами капитал теориясы адами ресурстарды сапалы жетілдіру процесін зерттейтінін түсіндірді. Адами капитал ұғымының мағынасы ретінде - бұл адамның қабілеттері, білімі, дағдыларының жиынтығы меңзеледі [11].

Қазіргі уақытта Қазақстандық экономикалық әдебиетте адами капитал проблемаларын жүйелі талдауға арналған тұтас зерттеулер жоқ. Қазақстандық экономист А.Г. Мұхамеджанова адами капиталды қазіргі 
заманғы қоғамдық өндірістің даму параметрлері мен үрдістеріне сай келетін жұмыскерлердің жасампаз, тұрақты жинақталатын және жаңартылатын қабілеттерінің сипаттамасы ретінде анықтады. Ол әлеуметтік шығындарды қайта бағдарлауды ұсынады және адами капиталға инвестицияның қажеттілігін ғылыми негіздейді [12]. А.Б. Майдырова мен И.В. Онюшеваның зерттеулерінде Қазақстан Республикасындағы ақпараттық экономика жағдайында мемлекеттің экономикалық саясатының адами капиталға әсері зерттелді [1314]. Сондай-ақ қазақстандық зерттеулерде елдің әлеуметтік-экономикалық саласындағы гендерлік саясаттың әдіснамалық негіздерін дамыту және ұлттың адами капиталын тиімді пайдалану проблемалары көрсетілген [15].

Адами капитал зияткерлік қызметке инвестициялар есебінен қалыптасады. Оның ішінде-тәрбие, білім, денсаулық, білім (ғылым), кәсіпкерлік қабілет және климат, еңбекті ақпараттық қамтамасыз ету, тиімді элитаны қалыптастыру, азаматтар мен бизнестің қауіпсіздігі және экономикалық еркіндік, сондай-ақ мәдениет, өнер және басқа да құрамдастар. Адам капиталы басқа елдерден көші-қон ағыны есебінен қалыптасады немесе оның кетуі есебінен азаяды деп айтуға болады [16].

Сонымен, отандық ғылымда адам капиталының мәні туралы бірыңғай түсінік жоқ және әртүрлі көзқарастар бар. Қазақстандық ғалымдар адами капиталдың түрлі аспектілерін, өмір сүру сапасын және жалпы адам дамуын зерттеумен айналысады [17-18]. Қазақстанның адами капиталын зерттеуде Қазақстан Республикасы Президентінің жанындағы Қазақстандық стратегиялық зерттеулер институты үлкен жұмыс жүргізуде. Алайда, белгілі бір сандық және сапалық индикаторлары бар адами капиталды бағалауда түпкілікті тәсіл табылған жоқ.

Авторлар «адами капитал» ұғымын кең мағынада қарастырады және демографиялық, әлеуметтік-экономикалық және экологиялық компоненттерді қамтиды. Осы тәсіл шеңберінде адами капиталдың даму деңгейінің статистикалық көрсеткіштер жүйесі әзірленді. Адам капиталы адамның даму процесінде өмір бойы қалыптасатындығын ескере отырып, зерттеу капиталдың осы түрін жинақтау, қалыптастыру және қолдану кезеңдеріне сәйкес жүргізілді. Жинақтау кезеңі - өмірдің бірінші жылындағы балалардың туу және өмір сүру кезеңі; қалыптасу кезеңі - білім алған сәттен бастап еңбек қызметін бастағанға дейінгі кезең; қолдану кезеңі - еңбек әрекетінің кезеңі.

\section{Дерек және әдістер}

Ақпараттық база ретінде Қазақстан Республикасының Стратегиялық жоспарлау және реформалар жөніндегі агенттігінің ұлттық статистика бюросының [19], ұлттық статистика бюросының ТДМ бойынша есептіліктің ұлттық платформасының [20], монографиялардың, ғылыми мақалалардың және т.б. ресми деректері қызмет етті.

Деректерді өңдеу барысында пайдаланылған қолданбалы бағдарламалар пакеттер: Excel электрондық кестелері, «Талдау» ақпараттық-аналитикалық жүйесі [21]. Ғылыми зерттеулерде геоақпараттық технологиялар, ArcGIS 10.2 бағдарламасы және т. б. қолданылды.

Мақаланы жазу кезінде жалпы ғылыми мен географиялық әдістер қолданылды: факторлық, статистикалық, аналитикалық, салыстырмалы географиялық, ГАЖ талдау. Динамикадағы салыстырмалы талдау үшін 2010-2020 жылдардағы деректер қарастырылды. Бұл зерттеу ресейлік ғалымдардың еңбектеріне [22-23] негізделген аймақтың адами капиталын кешенді бағалау әдістемесін ұсынады. Бірінші кезеңде факторлық талдау негізінде адами капиталдың кеңейтілген құрамдас бөліктеріне топтастырылған демографиялық, әлеуметтік, экономикалық және экологиялық адами капиталдың негізгі индикаторлары іріктеп алынды. Адами капитал адамның даму үрдісінде өмір бойы қалыптасатынын ескере отырып, капиталдың осы түрін жинақтау, қалыптастыру және пайдалану кезеңдері бойынша зерттеу жүргізілді. Жинақтау кезеңі - өмірдің бірінші жылындағы сәбилердің туу мен өмір сүру ұзақтығы; қалыптасу кезеңі - білім алған сәттен бастап еңбек қызметін бастағанға дейінгі кезең; қолдану кезеңі - еңбек әрекетінің кезеңі. Адами капиталдың интегралды индексін есептеу кезінде авторлар сандық талдау үшін ғана емес, сапалық талдау үшін де көрсеткіштерді таңдады. Білім және еңбек нарығына қатысты көрсеткіштерге көп көңіл бөлінді, өйткені адами капитал осы салаларда қалыптасады да және тұтынылады. Сондықтан адами капиталдың осы құрамдас бөліктерінің көрсеткіштері үшін сапалық талдау қолданылды. Осылайша, сапалық талдау үшін «Ұлттық бірыңғай тестілеудің орташа балы», «Орта білім беру ұйымдарының оқу жетістіктерін сырттай бағалаудың орташа балы» (ОЖСБ), «Жұмыспен қамтылған халықтың жоғары және толық емес жоғары білім». ОЖСБ Қазақстан Республикасында 2012 жылдан бастап енгізілгендіктен, мақалада бұл көрсеткіштің 2012-2019 жылдарға арналған статистикалық деректері қарастырылды. 
Екінші кезеңде адами капиталдың интегралды бағасын беретін жүйеде облыстың адами капиталының жағдайын бағалаудың құрамдас бөліктері қарастырылды.

Сонымен қатар, деректерді ұсынудың индекстік әдісі қолданылды, бұл жеке шкалаларды қолдана отырып, көптеген әртүрлі көрсеткіштерді өлшеуге және осы өлшемдерді бір шкалаға қосу арқылы азайтуға мүмкіндік береді. Индекстерді есептеудің әртүрлі әдістері бар. Біз негізгі индикаторлар үшін сызықтық масштабтау әдісін таңдадық. референттік нүктелерді анықтауға негізделген (индикаторлардың ең жоғарғы және ең төменгі мәндері). Егер көрсеткіштің өмір сүру сапасымен байланысы оң болса, есептеу (1) формула бойынша жүргізіледі:

$$
I=\frac{\mathrm{X}_{\mathrm{J}}^{\mathrm{i}}-\mathrm{X}_{\min \mathrm{i}}}{\mathrm{X}_{\max \mathrm{i}}-\mathrm{X}_{\min \mathrm{i}}},
$$

мұндағы - ј аймағының і-ші көрсеткіші;

$\mathrm{X}_{\text {mini- }}$ барлық j-ші аймақтар арасындағы I-ші көрсеткіштің ең төменгі мәні;

$\mathrm{X}_{\operatorname{maxi}}$ - барлық j аймақтар арасындағы I көрсеткіштің ең жоғарғы мәні. болса:

(2) формула бойынша, егер байланыс теріс

$$
I=1-\frac{\mathrm{X}_{\mathrm{J}}^{\mathrm{i}}-\mathrm{X}_{\min 1 \mathrm{i}}}{\mathrm{X}_{\max \mathrm{i}}-\mathrm{X}_{\min \mathrm{i}}}
$$

Өңірлердің адами капиталы жай-күйінің интегралды көрсеткішін есептеу үшін оның әрбір құрамдас бөлігінің маңыздылық коэффициенттері сараптамалық әдісті қолдана отырып, басымдықтарды белгілеу арқылы анықталды [22, 378 б.] (3).

Аймақтардың адами капиталының интегралдық көрсеткіші мынадай формула бойынша айқындалады:

$$
\mathrm{I}_{\mathrm{HC}}=0,20 \mathrm{Q}_{\mathrm{dem}}+0,32 \mathrm{Q}_{\mathrm{s}}+0,30 \mathrm{Q}_{\mathrm{e}}+0,18 \mathrm{Q}_{\mathrm{ecol}}
$$

мұнда,

$\mathrm{I}_{\text {нс}}$-аймақтардың адами капиталының интегралдық көрсеткіші;

$\mathrm{Q}_{\mathrm{dem}}{ }^{-}$аймақтардың адами капитал индикаторларын бағалаудың сараланған демографиялық көрсеткіштері;

$\mathrm{Q}_{\text {s- }}$ аймақтардың адами капитал индикаторларын бағалаудың мөлшерленген әлеуметтік көрсеткіштері;

$\mathrm{Q}_{\mathrm{e}}$ - аймақтардың адами капитал индикаторларын бағалаудың мөлшерленген экономикалық көрсеткіштері;
$\mathrm{Q}_{\text {ecol }}{ }^{-}$аймақтардың адами капитал индикаторларын бағалаудың мөлшерленген экологиялық көрсеткіштері;

Ұсынылған бағалау әдісінің негізінде аймақтардың адами капиталының салыстырмалы сипаттамасын алуға болады.

\section{Нәтижелер мен пікірталас}

Адами капиталдың деңгейін сипаттайтын негізгі демографиялық көрсеткіштерге - халық саны, халықтың өсу қарқыны, туу кезіндегі күтілетін өмір ұзақтығы, қартаю деңгейі, халықтың өлімі, нәресте өлімі және т.б.

Адами капиталдың қалыптасуының әлеуметтік-экономикалық факторларына мыналар жатады: денсаулық сақтау, халықтың білімі мен кәсіптік даярлығының жалпы деңгейі, еңбек нарығындағы білікті жұмыс күшімен қамтамасыз етілуі, еңбек нарығы, оның сандық және сапалық сипаттамалары, қызметкерлердің еңбек жағдайлары, кәсіпорындардың материалдық қамтамасыз етілу және техникалық-экономикалық даму деңгейі, олардың әлеуметтік инфрақұрылымының даму деңгейі, экономика салаларының даму деңгейінің талаптарына сәйкес қызметкерлердің біліктілігін арттыру, кәсіпорындар персоналының әлеуметтік дамуы.

Адами капиталдың қалыптасуына әсер ететін тағы бір фактор - экономикалық факторлар. Адами капиталдың экономикалық факторларын сипаттайтын көрсеткіштер: халықтың жан басына шаққандағы орташа ақшалай табысы, табысы ең төменгі күнкөріс деңгейінен төмен халықтың үлесі, экономикалық белсенді халықтың үлесі, жұмыспен қамтылған халықтың білім деңгейі, бір жұмысшының орташа айлық жалақысы, жұмыссыздық деңгейі және т.б.

Адами капиталды қалыптастыруға әсер ететін экологиялық факторларға белгілі бір аймақтардың тұрғындары тұратын жалпы экологиялық жағдай мен табиғи-климаттық жағдайлар жатады. Экологиялық жағдай табиғи ресурстардың болуы мен сапасы, адам мен қоршаған ортаның өзара әрекеттесуі, антропогендік қызметтің қоршаған орта жағдайына әсері, осы қызмет нәтижесінде қоғам келтірген зиянды өтеу деңгейі, шикізаттың жаңартылатын түрлерін тұтыну сияқты көрсеткіштермен сипатталады.

Біздің зерттеуімізде экологиялық факторларды сипаттайтын негізгі индикаторлар тұрақты көздерден атмосфераға шығатын ластаушы заттардың шығарындылары, қоршаған ортаны қорғауға жұмсалатын ағымдағы шығындар, қауіпті табиғи құбылыстардың саны, респонденттердің ауа тазалығына 
қанағаттану туралы сауалнамасы (онда шығарындылардың, түтіннің, шаң мен кірдің болмауы) болып табылады. Бұл көрсеткіштер шартты болып табылады.

Аймақтар арасындағы салыстырулар саясат шараларын қабылдау процесін жеделдетуі мүмкін, егер әр түрлі елдердегі уақыт пен жағдайдың өзгеруін бақылау үшін тікелей өлшеулер негізінде мазмұнды көрініс жасай алатын мөлдір көрсеткіш қолданылса, артады.
Бұл зерттеу аймақтың адами капиталын кешенді бағалау әдістемесін ұсынады. Факторлық талдау негізінде адами капиталдың интегралды құрамдас бөліктеріне топтастырылған адами капиталдың негізгі көрсеткіштері таңдалды: демографиялық, әлеуметтік, экономикалық және экологиялық (1-сурет). Республикалық адами капиталдың интегралдық индексін есептеу кезінде авторлар сандық талдау үшін ғана емес, сапалық үшін де индикаторларды таңдады.

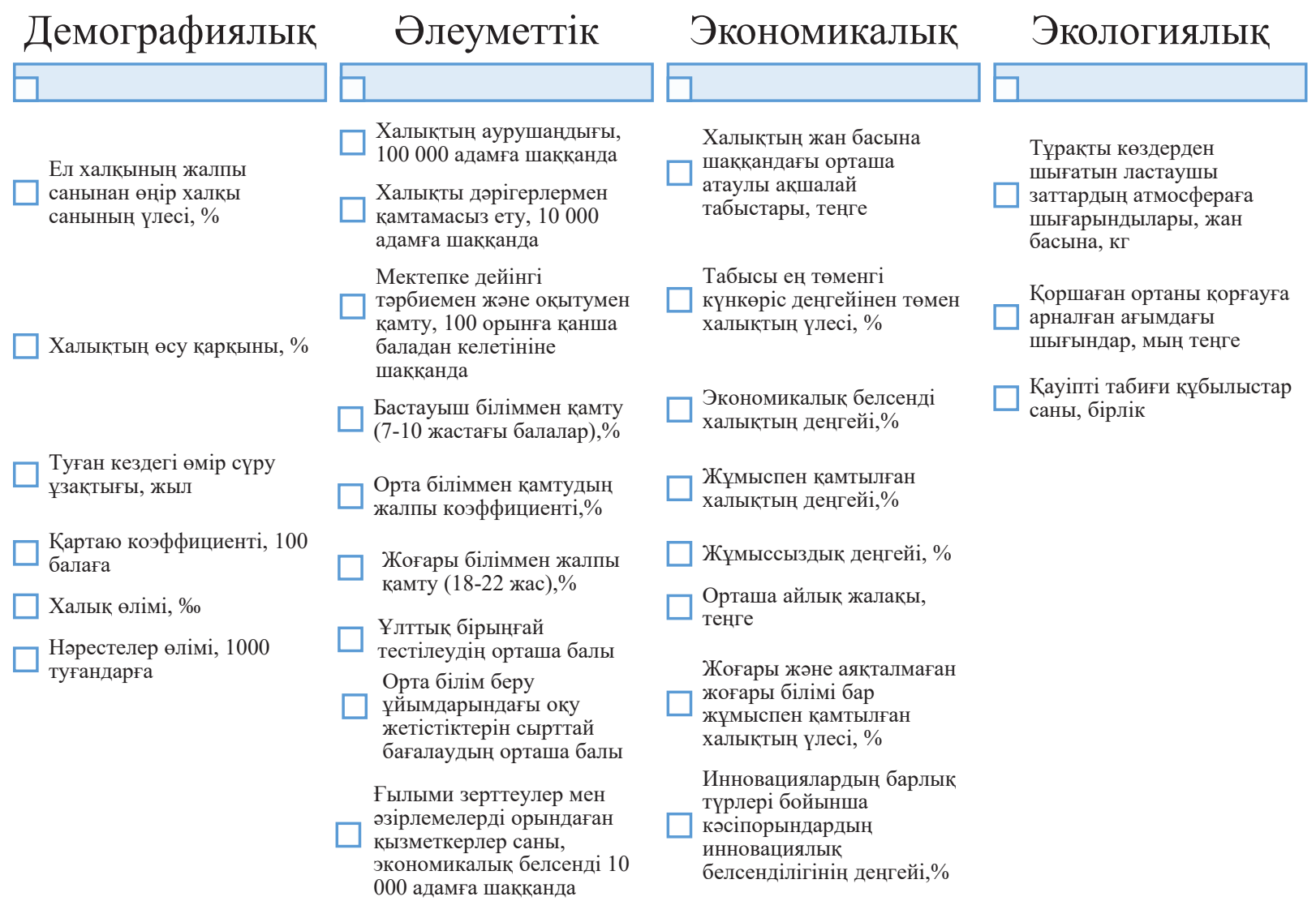

1-сурет - Қазақстан Республикасы өңірлерінің адами капиталының жай-күйін бағалау индикаторларының құрылымы

Figure 1 - The structure of indicators for assessing the state of human capital in the regions of the Republic of Kazakhstan

Білім беру және еңбек нарығына қатысты көрсеткіштерге көп көңіл бөлінді, өйткені адами капитал осы салаларда қалыптасады және сатылады (тұтынылады). Еңбек және білім саласындағы зерттеулер жоғары білім жұмыс орнына қарамастан қызметкердің жалақысын едәуір арттыратынын растайды. Нәтижелер жоғарғы оку орнында (ЖОО) әрбір қосымша оқу жылы жалақы деңгейін 6-7\% ға, ал техникалық және кәсіптік,орта білімнен кейінгі білім беру ұйымдарында қосымша оку жылы 3,2\%-ға арттыруға ықпал ететінін көрсетті [24]. Сондықтан адами капиталдың осы компоненттерінің индикаторлары үшін сапалы талдау қолданылды. Осылайша, сапалы талдау үшін «Ұлттық бірыңғай тестілеудің орташа балы», «орта білім беру ұйымдарындағы оқу жетістіктерін сырттай бағалаудың орташа балы» (ОЖСБ), «жоғары және аяқталмаған жоғары білімі бар жұмыспен қамтылған халықтың үлесі»сияқты ұлттық көрсеткіштер іріктелді [25].

Қазақстан Республикасында білім беру сапасын бағалаудың ішкі және халықаралық құралдары пайдаланылады. Ұлттық бірыңғай тестілеу (ҰБТ) және 2012 жылдан бастап оку 
жетістіктерін сырттай бағалау (ОЖСБ) ел ішіндегі қорытынды және аралық қималар негізінде оқушылардың білім деңгейі туралы ақпарат ұсынады. ОЖСБ Қазақстан Республикасында 2012 жылдан бастап енгізілгендіктен, мақалада 2012-2019 жж. статистикалық деректер қарастырылды.

Бүгінгі таңда жоғары білім қазақстандық қоғамның негізгі қажеттілігіне айналды.
Халықтың білім сапасы көп жағдайда мемлекеттің ғылыми-техникалық дамуын анықтайды және жекелеген жұмысшылардың, кә-сіпорындардың, экономика салаларының және елдің бәсекеге қабілеттілігін арттыруға ықпал етеді. 2002-2019 жж. жоғары біліммен жалпы қамту (18-22 жас) 49,5\%-дан 67,0\%-ға өсті (atlassd.kaznu.kz/) (2-сурет).

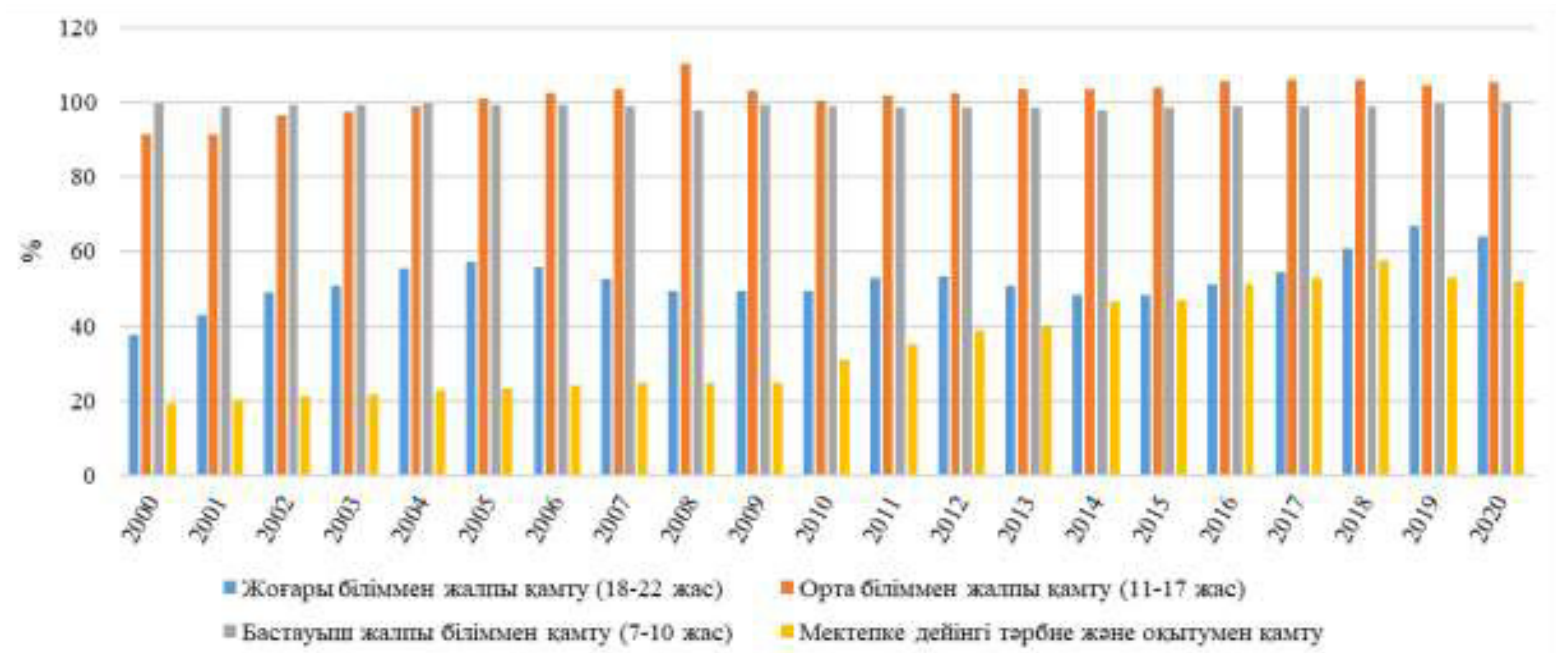

2 сурет - Қазақстан Республикасының халқын білім берумен қамту динамикасы (2000-2020 жж.)

Figure 2 - Dynamics of gross enrolment in education of the population in the Republic of Kazakhstan (2000-2020)

Аймақтағы адам капиталының жайкүйін бағалау компоненттерін адами капиталға интегралды баға беретін жүйеде қарастырған жөн. Өңірлердің адами капиталы жай-күйінің интегралдық көрсеткішін есептеу үшін оның әрбір индикаторының маңыздылық коэффициенттерін анықтау қажет. Коэффициенттер басымдықтарды сараптамалық әдіспен белгілеу арқылы айқындалады. Ұсынылған бағалау әдісінің негізінде аймақтардың адами капиталының салыстырмалы сипаттамасын алуға болады. Бағалау мақсатында көрсеткіштердің мәндері стандартталды. Есептеу нәтижелері 1-кестеде келтірілген.

Республика өңірлерін адами капиталын интегралдық бағалау бойынша жүргізілген есептеулер жинақталған адами капитал деңгейі бойынша мынадай өңірлерді шартты түрде бөліп көрсетуге мүмкіндік береді: «таланттарға арналған магнит», «өнеркәсіптік белдеу», «индустриялық-аграрлық доға», «периферия» (3-сурет).

2019 жылы ең жоғары интегралдық көрсеткіш Нұрсұлтан $(0,660)$ және Алматы $(0,604)$ қалаларында болды. Бұл өңірлер шартты түрде «таланттарға арналған магниттер» деп белгіленген, мұнда экологиялық жағдайдың өзектілігіне ие болатын Алматы қаласынан басқа барлық құрамдастар бойынша жоғары көрсеткіштер байқалады. Нұрсұлтан және Алматы қалалары индустриядан кейінгі мамандануымен, халықтың жоғары табысымен, өмір сүру ұзақтығының жоғары болуымен, туудың төмен болуымен және Халықтың көші-қон ағынының жоғары болуымен ерекшеленеді.

«Өнеркәсіптік белдеу» санатына біріктірілген Атырау, Ақтөбе, Батыс Қазақстан, Маңғыстау, Қарағанды облыстары экономиканың шикізаттық мамандануымен, жоғары табыс деңгейімен, орташа өмір сүру ұзақтығымен және бала туудың жоғары деңгейімен ерекшеленеді. Сондай-ақ, 2018 жылы өзінің мегаполис мәртебесін алған Республикалық маңызы бар Шымкент қаласы да осы санатқа жатады [26]. Жергілікті бюджет өсіп, әлеуметтік маңызы бар нысандар салына бастады. Бұрын Шымкент қаласы аграрлық аймақ - Оңтүстік Қазақстан облысының орталығы болған. Екі жыл ішінде мегаполис «өнеркәсіптік белдеу»санатына өтті. «Өнеркәсіптік белдеу» санатындағы өңірлер үшін жоғары экологиялық көрсеткіштер тән. Бұл факт осы өнеркәсіптік өңірлерде өзінің экологиялық осалдығына байланысты қоршаған ортаны қорғауға жұмсалатын республика бойынша ең жоғары шығындардың болуымен түсіндіріледі. 


\section{DEMOGRAPHY, HUMAN RESOURCES AND THE LABOR MARKET}

1-кесте - Қазақсан Республикасының аймақтарын адами капиталын интегралдық бағалау (2010-2019 жж.)

Table 1 - Integrated assessment of the human capital of the regions of the Republic of Kazakhstan (2010-2019)

\begin{tabular}{|l|c|c|c|c|c|c|c|c|c|c|c|}
\hline \multirow{2}{*}{\multicolumn{1}{|c|}{ Аймақтар }} & \multicolumn{7}{|c|}{ Адами капиталдың интегралдық индексі } \\
\cline { 2 - 13 } & 2010 & 2011 & 2012 & 2013 & 2014 & 2015 & 2016 & 2017 & 2018 & 2019 & 2020 \\
\hline Ақмола & 0,38 & 0,34 & 0,39 & 0,38 & 0,44 & 0,39 & 0,44 & 0,45 & 0,42 & 0,44 & 0,41 \\
\hline Ақтөбе & 0,50 & 0,55 & 0,50 & 0,50 & 0,52 & 0,44 & 0,47 & 0,52 & 0,49 & 0,47 & 0,49 \\
\hline Алматы & 0,38 & 0,41 & 0,41 & 0,44 & 0,45 & 0,40 & 0,42 & 0,45 & 0,42 & 0,45 & 0,44 \\
\hline Атырау & 0,56 & 0,56 & 0,57 & 0,58 & 0,56 & 0,55 & 0,52 & 0,55 & 0,52 & 0,53 & 0,52 \\
\hline $\begin{array}{l}\text { Батыс Қазақстан } \\
\text { облысы }\end{array}$ & 0,49 & 0,50 & 0,51 & 0,50 & 0,49 & 0,42 & 0,45 & 0,49 & 0,44 & 0,46 & 0,42 \\
\hline Жамбыл & 0,46 & 0,41 & 0,41 & 0,40 & 0,45 & 0,35 & 0,37 & 0,40 & 0,40 & 0,40 & 0,39 \\
\hline Қарағанды & 0,44 & 0,42 & 0,43 & 0,43 & 0,44 & 0,35 & 0,39 & 0,46 & 0,45 & 0,45 & 0,44 \\
\hline Қостанай & 0,43 & 0,44 & 0,44 & 0,43 & 0,46 & 0,38 & 0,38 & 0,41 & 0,37 & 0,40 & 0,37 \\
\hline Қызылорда & 0,39 & 0,36 & 0,36 & 0,39 & 0,39 & 0,36 & 0,39 & 0,44 & 0,41 & 0,39 & 0,37 \\
\hline Маңғыстау & 0,41 & 0,38 & 0,43 & 0,44 & 0,51 & 0,49 & 0,47 & 0,49 & 0,49 & 0,46 & 0,46 \\
\hline Павлодар & 0,41 & 0,42 & 0,46 & 0,43 & 0,44 & 0,38 & 0,39 & 0,43 & 0,40 & 0,39 & 0,38 \\
\hline $\begin{array}{l}\text { Солтүстік Қазақстан } \\
\text { облысы }\end{array}$ & 0,36 & 0,33 & 0,38 & 0,36 & 0,35 & 0,32 & 0,32 & 0,34 & 0,30 & 0,30 & 0,29 \\
\hline Түркістан* & 0,43 & 0,42 & 0,44 & 0,40 & 0,39 & 0,35 & 0,39 & 0,36 & 0,35 & 0,38 & 0,39 \\
\hline $\begin{array}{l}\text { Шығыс Қазақстан } \\
\text { облысы }\end{array}$ & 0,37 & 0,39 & 0,40 & 0,37 & 0,44 & 0,37 & 0,39 & 0,47 & 0,40 & 0,41 & 0,40 \\
\hline Нұрсұлтан қ. & 0,54 & 0,54 & 0,56 & 0,59 & 0,69 & 0,70 & 0,67 & 0,69 & 0,67 & 0,66 & 0,64 \\
\hline Алматы қ. & 0,56 & 0,54 & 0,58 & 0,56 & 0,55 & 0,58 & 0,63 & 0,63 & 0,58 & 0,60 & 0,59 \\
\hline Шымкент к** & - & - & - & - & - & - & - & - & 0,45 & 0,47 & 0,44 \\
\hline
\end{tabular}

* 2018 жылға дейін Оңтүстік Қазақстан облысы

** 2018 жылдан бастап Республикалық маңызы бар қала

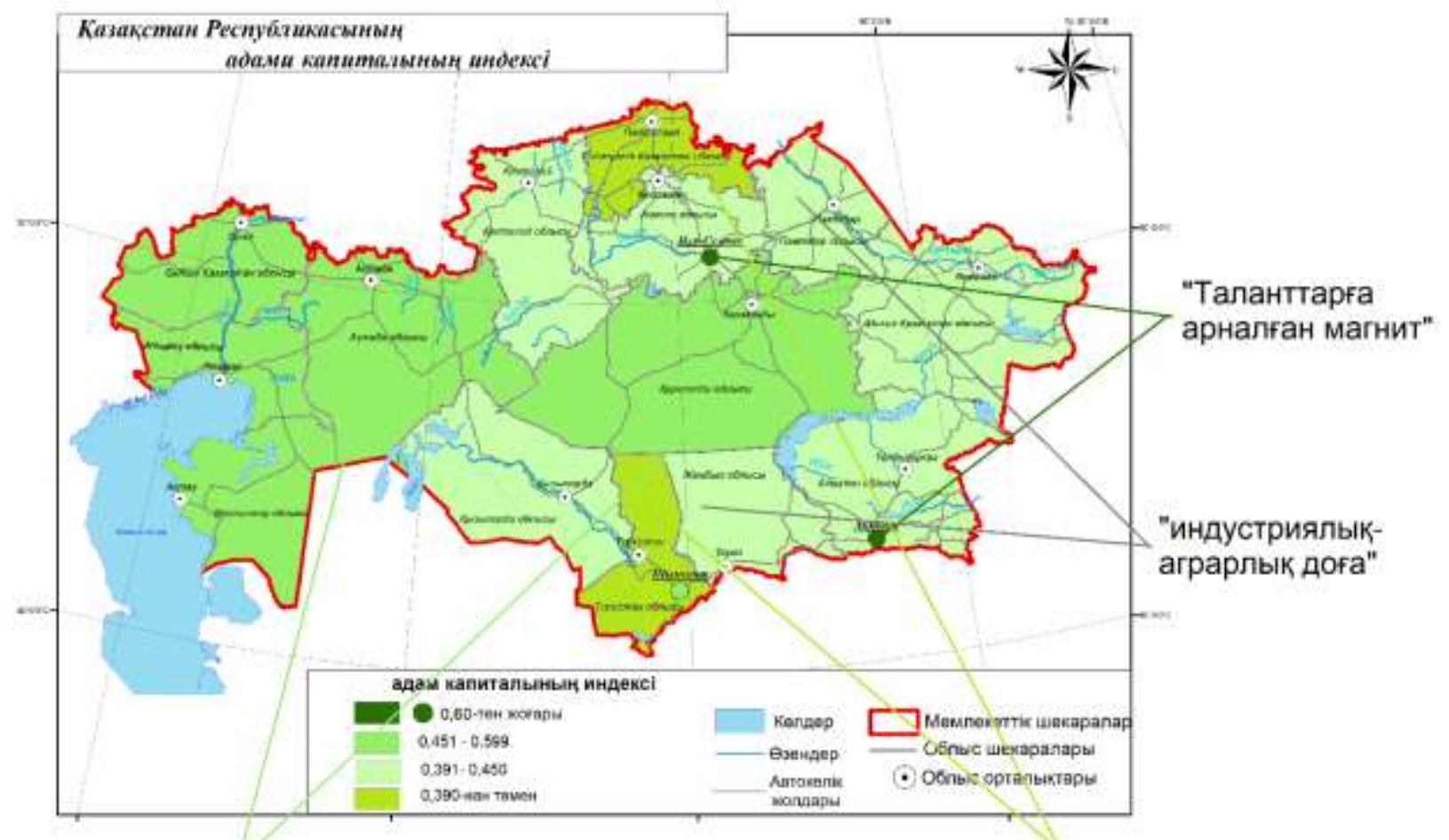

\section{Өнеркәсіптік белдеу}

Периферия

3 - сурет - 2020 ж. жинақталған адами капитал деңгейі бойынша Қазақстан Республикасы өңірлерінің типологиясы

Figure 3 - Typology of regions of the Republic of Kazakhstan by the level of accumulated human capital for 2020 
«Индустриялық-аграрлық доға» (Алматы, Ақмола, Шығыс Қазақстан, Қостанай, Жамбыл, Қызылорда және Павлодар облыстары) өңірлері үшін атауының өзі айтып отырғандай, экономиканың индустриялық-аграрлық типі, халық табысының орташа деңгейі, өмір сүру ұзақтығының төмендігі, экологиялық жағдайға байланысты сырқаттанушылықтың жоғары болуы және бала туудың төмен болуы тән. Бұл аймақтарда ірі өнеркәсіптік нысандар да, ауыл шаруашылығы да дамыған.

Солтүстік Қазақстан және Түркістан облыстары кіретін «переферия» өңірлері Жұмыспен қамтудың аграрлық түрімен, табыс деңгейінің төмендігімен, орташа өмір сүру ұзақтығымен сипатталады. Этникалық құрамы, менталитеті және ұлттық ерекшеліктері аясында оңтүстік өңір - Түркістан облысына бала туудың жоғары болуы тән, ал солтүстік өңір - Солтүстік Қазақстан облысына халықтың көші-қон ағыны, бала туудың төмен болуы тән.

2010-2020 жылдардағы Қазақстан өңірлерінің адами капиталының экономикалық, әлеуметтік, демографиялық және экологиялық құрамдас көрсеткіштерінің индикаторлары негізінде әртүрлі әдістемелер синтезі негізінде адами капиталдың интегралдық индекстері есептелді [23, 27-29].

2020 жылғы 16 наурызда Қазақстанда алғаш рет коронавирус пандемиясының өршуіне байланысты төтенше жағдай режимі енгізілді. Қазақстан билігі бірден бірқатар маңызды шаралар қабылдады. Мұндай шараларға қалаларды жабу, төтенше жағдай режимін енгізу, әлеуметтік қашықтықты ұстануға шақыру, шағын және орта бизнесті тоқтату, білім беру мекемелерін жабу, бұқаралық іс-шараларды өткізуге тыйым салу кірді. Үкімет COVID-19 аясында туындаған дағдарысқа жылдам жауап берді және шағын және орта кәсіпкерлікті және халықты қолдауға бағытталған ЖІӨ-нің шамамен $6 \%$ мөлшерінде бюджеттік ынталандыру пакетін ұсынды: халыққа қарыздарды төлеуді кейінге қалдыру; шағын және орта кәсіпкерлікті жеңілдікпен несиелендіру және несиелер бойынша кейінге қалдыру; компаниялардың жекелеген топтарына мүлік салығын, жер салығын және табыс салығын төлеуден босату; пандемия салдарынан өзін-өзі жұмыспен қамтығандарға және жұмыс орнын жоғалтқандарға ақшалай төлемдер; көктемгі дала жұмыстарын және ауыл шаруашылығы саласын сатып алуды қаржыландыру; табысынан айырылу бойынша әлеуметтік төлемдер және т. б.
Осыған қарамастан, “дағдарыстық» 2020 жыл үшін адами капитал көрсеткіштерінің 4 блогының барлық индикаторларының төмендеуі байқалады. Осы жылы білім беру мекемелерінің жабылуына байланысты орта мектеп - ОЖСБ-да білім беру сапасына мониторинг жүргізілген жоқ және ҚР Білім және Ғылым Министрінің өкімімен 2020 жылдан бастап облыстар, аудандар және мектептер бөлінісінде "ҰБТ орташа баллы" көрсеткіші білім беру статистикасында жүргізілмейді. Осыған байланысты, ҚР өңірлерінде адами капиталдың даму деңгейінің интегралдық индексін есептеу кезінде 2020 жылға бұл көрсеткіштер енгізілмеген.

Дегенмен, 2020 жылы ҚР өңірлерінде адами капиталдың даму деңгейінің интералдық индексінің есептеулері демографиялық құрамдас бөлік есебінен өсу жүріп жатқан Ақтөбе және Түркістан облыстарынан басқа барлық өңірлерде көрсеткіштің төмендегенін көрсетеді.

COVID-19 салдары әлі де ұзаққа созылады. Мысалы, мектептерді қысқа уақытқа жабу академиялық үлгерімдегі алшақтықты арттырады. Егер көрсеткіштерді есептеу бойынша Қазақстанда COVID-19 өршуіне дейін туған бала өз әлеуетінің 63\%-ын ғана іске асыра алады деп күтілсе, онда пандемия білім алушылардың мүмкіндіктерін одан әрі шектейді. Мектептегі оқытудың ұзақтығы мен сапасы болашақта табыс табу мүмкіндігімен байланысты болғандықтан, мектептердің жабылуы осыған тап болған адамдардың кірісін азайтуы мүмкін. Зерттеулер мен консалтинг орталығының бағалауы бойынша Қазақстанда 2020 жылғы наурыз-маусымда мектептердің 4 ай жабылуының нәтижесінде осы ұрпақтың болашақ табыстары 2,9\%-ға қысқаруы мүмкін, бұл жалпы экономикалық шығындардың жыл сайын 1,9 млрд долларға дейін баламасы болып табылады.

Осылайша, жүргізілген есептеулер Қазақстанның аумақтық сәйкессіздіктерін анықтауға және адами капиталдың әртүрлі деңгейі бар аймақтардың топтарын анықтауға мүмкіндік жасалған. Адами капитал деңгейі бойынша анықталған елдің 4 өңірінде көрсеткіштердің үлкен алшақтығы байқалады.

\section{Қорытынды}

Өңірлер мен мемлекеттің әлеуметтікэкономикалық дамуының қазіргі парадигмасындағы адами капитал ұзақ мерзімді экономикалық өсудің маңызды көздерінің бірі ретінде танылады. Адамның дамуы ұлттық экономикалық жүйелердің өсуі мен дамуының жаңа модельдеріндегі негізгі факторлардың 


\section{DEMOGRAPHY, HUMAN RESOURCES AND THE LABOR MARKET}

бірі ретінде қарастырылады. Қазақстан Республикасының барлық стратегиялық бағдарламаларында адами капиталды дамытуға үлкен мән беріледі. Аумақтың адами капиталын дамыту-күрделі мәселе. Республика аймақтарының әлеуметтік-экономикалық дамуының барлық факторлары адамның дамуына тікелей немесе жанама әсер етеді. Сонымен бірге адами капиталдың есептелген индексі кешенді көрсеткіш ретінде қоғамның әлеуметтік-экономикалық даму деңгейін және оның одан әрі өсу әлеуетін көрсетеді.

Жүргізілген есептеулер Қазақстанның аумақтық сәйкессіздіктерін анықтауға және адами капиталдың әртүрлі деңгейі бар аймақтардың топтарын анықтауға мүмкіндік жасалған. Талдау көрсеткендей, демографиялық және экономикалық көрсеткіштердің тұрақты өсуі бар Нұр-сұлтан және Алматы қалалары «таланттарға арналған магнит» санатына жатады, бұл заңды, өйткені бұл қалалар табиғи және механикалық өсу есебінен халқының саны жоғары елдің негізгі ғылыми, мәдени, өндірістік және қаржы орталықтары болып табылады. Бұл өңірлерде салыстырмалы түрде жоғары әлеуметтік көрсеткіштер байқалады.

«Өнеркәсіптік белдеу» өңірлері жоғары және орташа демографиялық индикаторлармен сипатталады.Экономикалық көрсеткіштер бұл өңірлерде мұнай-газ,тау-кен өндіру және металлургия өнеркәсібін дамыту есебінен өсуді көрсетіп отыр. Әлеуметтік көрсеткіштердің жоғары деңгейі тек Алматы қаласына ғана тән. Қалған өңірлер үшін әлеуметтікэкономикалық көрсеткіштердің басым бөлігі жоғары деңгейде жеткіліксіз.

Алматы, Ақмола, Шығыс Қазақстан, Костанай, Қызылорда, Жамбыл, Павлодар облыстары кіретін «индустриялық-аграрлық доға» санатындағы өңірлерде орташа демографиялық және орташа экономикалық көрсеткіштер, сондай-ақ төмен әлеуметтік көрсеткіштер байқалады.

Адами капитал деңгейі бойынша келесі санат - «периферия». Бұл санатқа республикада екі өңір жатады: Солтүстік Қазақстан және Түркістан облыстары. Екі өңірде республиканың солтүстік және оңтүстік шетінде орналасқан, әлеуметтік-экономикалық көрсеткіштері төмен. Этникалық құрамы, менталитеті және ұлттық ерекшеліктері аясында оңтүстік өңір - Түркістан облысына бала туудың жоғары болуы тән, ал солтүстік өңір - Солтүстік Қазақстан облысына халықтың көші-қон ағыны, бала туудың төмен болуы тән.
Қазақстан Республикасы - халқы біркелкі емес және негізінен периметрі бойынша бөлінген, аумағы үлкен ел. Экономикалық, әлеуметтік, демографиялық және экологиялық индикаторларды талдау елдің әртүрлі бөліктерінде әртүрлі адами капиталдың қалыптасқанын анықтады. Адами капитал деңгейі бойынша анықталған елдің 4 өңірінде көрсеткіштердің үлкен алшақтығы байқалады, сондықтан постиндустриалды «дарындыларға арналған магнит» пен аграрлық «периферия» арасындағы халық табысы деңгейінің айырмашылығы 4 есе құрайды. Ic жүзінде бізде екі экстремум бар, яғни. 30 елдің қатарында 70-80 орында тұрған Қазақстан Республикасы бар.

Осыған байланысты, еліміздің экономикасын одан әрі дамыту үшін әр аймақтарда адами капиталды дамытуға назар аудару өте маңызды деп санаймыз, өйткені ол көбінесе экономиканың тиімді дамуын анықтайды.

\section{Пайдланылдан әдебитеттер тізімі}

1 . Қазақстан Республикасының 2025 жылға дейінгі стратегиялық даму жоспары Қазақстан Республикасы Президентінің 2018 жылғы 15 ақпандағы № 636 Жарлығымен бекітілген.

2 . Petty. W. The Economic Writings of Sir William Petty, together with The Observa $\neg$ tions upon Bills of Mortality, more probably by Captain John Graunt, ed. Charles Henry Hull. - Cambridge University Press. 1989.

3 . Becker. G.S. Human Capital. A Theoretical and Empirical Analysis, with Special Reference to Education. - New York. New York and London, 1964, $187 \mathrm{p}$.

4 . Kuznets. S. Economic Growth of Nations. Total Output and Production Structure. -Cambridge, Mass., The Belknap Press of Harvard University Press, 1971. - $363 \mathrm{p}$.

5 . Schultz. T. Investment in Human Capital. The Role of Education and of Research. - New York, The Free Press, London, Collier-Macmillan Limited, 1971. $-272 p$.

6 . Фишер С., Дорнбуш Р., Шмалензи Р. Экономика. Economics. Пер. со 2-го англ. изд. - М.: Дело ЛТД, 1995 - 864c.

7 . Han, J. S., \& Lee, J. W. (2020). Demographic change, human capital, and economic growth in Korea // Japan and the World Economy, 53, 100984.

8 . Дятлов С.А. Основы теории человеческого капитала. - Санкт-Петербург: СПбУЭФ, 1994. - 160 с.

9 . Добрынин А., Дятлов С., Коннов В., Курганский С. Производительные силы человека: структура и формы проявления. - Санкт-Петербург, СПбУЕФ, 2006. - 163 с.

10 . Корчагин Ю.А. Российский человеческий капитал: фактор развития или деградации?: Монография. - Воронеж: ЦИРЭ, 2005. - 252c. 
11 . Капелюшников Р.И. Сколько стоит человеческий капитал России? // Вопросы экономики. - 2013. - № 1. - С. 27-47.

12 . Мухамеджанова А.Г. Человеческий капитал в современной экономике Казахстана (теория, методология, приоритеты развития): диссертация на соискание ученой степени: д.э.н. Алматы, 2003 - 263 c.

13 . Майдырова А.Б. Человеческий капитал нации в условиях формирования информационного общества: методологический аспект. Акад. гос. упр. при Президенте Республики Казахстан. Астана : Акад. гос. упр. при Президенте Республики Казахстан, 2008. - 167 с.

14 . Онюшева И.В. Человеческий капитал Республики Казахстан как фактор повышения конкурентоспособности национальной экономики: Диссертация на соискание ученой степени доктора философии (PhD): 6D050600. Экономика. Университет международного бизнеса, Алматы, 2013.

15 . Сейтхожина Д. А. Человеческий капитал в условиях формирования гендерного равенства в социальной сфере Республики Казахстан: диссертация на соискание ученой степени кандидата экономических наук: Специальность: 08.00.01. - Экономическая теория. Карагандинский экономический университет Казпотребсоюза Караганда, 2008 - 193c.

16 . Сыдыков Е.Б. Человеческий капитал и интеллектуальная миграция Республики Казахстан в контексте формирования ЕЭП Казахстана, России и Беларуси. Отчет научного проекта. Евразийский национальный университет им. Л.Н.Гумилева. Астана, 2014.

17 Nyussupova. G., Kalimurzina A. The dynamics of sex-age structure of the population in urban and rural areas in the Republic of Kazakhstan in the years 1991-2013// Bulletin of Geography. - 2016 - № 31. C. $87-111$

18 . Мельдаханова М.К., Калиева С.А. Человеческий капитал в условиях обеспечения конкурентоспособности национальной экономики: современная концепция, приоритеты и механизмы реализации. под ред. Мельдахановой М.К. - Алматы : ИЭ КН МОН РК, 2012. - 420с.

19 . Бюро национальной статистики, 2021 [обновлено 20 октября 2021; процитировано 30 октября 2021]. Доступно: www.stat.gov.kz

20 . Национальная платформа отчетности по ЦУР, 2021 [обновлено 20 октября 2021; процитировано 30 октября 2021]. Доступно: https:// kazstat.github.io/sdg-site-kazstat/ru/

21 . Информационно-аналитическая система Талдау, 2021 [обновлено 20 октября 2021; процитировано 30 октября 2021]. Доступно: https:// taldau.stat.gov.kz/

22 . Serebryakova. N.A., Volkova. S.A., Volkova. T.A. Human integralassessment methodology capital of the region// Vestnik VGUIT [Proceedings of VSUET]. 2019. - № 81(3). - C.375-380.

23 . Зубаревич Н.В. Социальное развитие регионов России: проблемы и тенденции переходного периода. - М.: Едиториал УРСС, 2003. - 264 с.
24 . Golenkova. Z.T., Kosharnaya. G.B., Kosharnyy. V.P. Influence of Education on Improved Competitiveness of Employees in the Labour Market. Integratsiya obrazovaniya //Integration of Education. 2018. № 22(2). - C.262-273.

25 . Nyussupova G., Aidarkhanova G., Young S. S. The impact of the transformation of the economy of the Republic of Kazakhstan on the reproduction of human capital: socio-economic aspect // Studies of the Industrial Geography Commission of the Polish Geographical Society. - 2021. - № 35(2). - C. 38-52.

26 . «Қазақстан Республикасының әкімшілікаумақтық құрылысының кейбір мәселелері туралы» Қазақстан Республикасы Президентінің 2018 жылғы 19 маусымдағы № 702 жарлығы.

27 . World Development Report The Changing Nature of Work. - World Bank: 2019.

28 . Mincer. J., Polachek. S. Family investments in human capital: Earnings of women// Journal of Political Economy. - 1974. - № 82. - C. 76-108.

29 . Kraay. A. Methodology for a World Bank Human Capital Index. - Policy Research Working Paper. $-2018,8593$.

\section{References}

1. [Strategic development plan of the Republic of Kazakhstan until 2025]. Qazaqstan Respýblıkasynyń 2025 jylǵa deıingi strategılalyq damý jospary, approved by the Decree of the President of the Republic of Kazakhstan dated February 15, 2018 No. 636. (In Kaz).

2. Petty, W. (1989). The Economic Writings of Sir William Petty, together with The Observa-tions upon Bills of Mortality, more probably by Captain John Graunt, ed. Charles Henry Hull. Cambridge University Press.

3. Becker, G.S. (1964). Human Capital. A Theoretical and Empirical Analysis, with Special Reference to Education, New York. New York and London.

4. Kuznets, S. (1971). Economic Growth of Nations. Total Output and Production Structure. -Cambridge, Mass., The Belknap Press of Harvard University Press.

5. Schultz .T. Investment in Human Capital. The Role of Education and of Research. - New York, The Free Press, London, Collier-Macmillan Limited.

6. Fischer, S., Dornbusch R., \& Shmalenzi, R. (1995). [Economics]. E'konomika. Transl. from the 2nd eng. ed., M.: Delo LTD.

7. Han, J.S., \& Lee, J.W. (2020). Demographic change, human capital, and economic growth in Korea. Japan and the World Economy, 53, 100984.

8. Dyatlov, S.A. (1994). [Foundations of the theory of human capital]. Osnovy teorii chelovecheskogo kapitala St. Petersburg: SPbUEF.

9. Dobrynin, A., Dyatlov, S., Konnov, V., \& Kurgan, S. (2006). [The productive forces of man: structure and forms of manifestation]. Proizvoditel `ny`e sily` cheloveka: struktura i formy' proyavleniya Saint Petersburg. SPbUEF.

10. Korchagin, Yu.A. (2005) [Russian human capital: a factor of development or degradation?] 
Rossijskij chelovecheskij kapital: faktor razvitiya ili degradaczii? Monograph, Voronezh: TSIRE.

11. Kapelyushnikov, R.I. (2013). [How much is Russia's human capital worth? Part I. Questions of economics]. Skol'ko stoit chelovecheskij kapital Rossii? Voprosy` e'konomiki, 1, 27-47.

12. Mukhamedzhanova, A.G. (2003). [Human capital in the modern economy of Kazakhstan (theory, methodology, development priorities)]. Chelovecheskij kapital V sovremennoj e'konomike Kazakhstana (teoriya, metodologiya, prioritety razvitiya): dissertation for an academic degree: Doctor of Economics, Almaty.

13. Maydyrova, A.B. (2008). [Human capital of the nation in the formation of the information society: methodological aspect]. CHelovecheskij kapital nacii v usloviyah formirovaniya informacionnogo obshchestva: metodologicheskij aspect. Acad. state ex. under the President of the Republic of Kazakhstan, Astana.

14. Onyusheva, I.V. (2013). [Human capital of the Republic of Kazakhstan as a factor in increasing the competitiveness of the national economy]. Chelovecheskij kapital Respubliki Kazakhstan kak faktor povy`sheniya konkurentosposobnosti naczional'noj e'konomiki: Dissertation for the degree of Doctor of Philosophy (PhD): 6D050600 - Economics / University of International Business, Almaty.

15. Seytkhozhina, D.A. (2008) . [Human capital in the context of the formation of gender equality in the social sphere of the Republic of Kazakhstan]. Chelovecheskij kapital $\mathrm{v}$ usloviyakh formirovaniya gendernogo ravenstva $\mathrm{v}$ soczial'noj sfere Respubliki Kazakhstan.: dissertation for the degree of candidate of economic sciences: Specialty: 08.00.01., Economic theory, Karaganda, 193.

16. Sydykov, E.B. (2014). [Human capital and intellectual migration of the Republic of Kazakhstan in the context of the formation of the CES of Kazakhstan, Russia and Belarus]. Chelovecheskij kapital i intellektual naya migracziya Respubliki Kazakhstan v kontekste formirovaniya EE'P Kazakhstana, Rossii i Belarusi. Scientific project report. Eurasian National University. L.N. Gumilyov, Astana.

17. Nyussupova, G., \& Kalimurzina, A. (2016). The dynamics of sex-age structure of the population in urban and rural areas in the Republic of Kazakhstan in the years 1991-2013. Bulletin of Geography, 31, 87111 .

18. Meldakhanova, M.K., \& Kalieva, S.A. (2012). [Human capital in the context of ensuring the competitiveness of the national economy: modern concept, priorities and implementation mechanisms]. Chelovecheskij kapital v usloviyakh obespecheniya konkurentosposobnosti naczional'noj e`konomiki: sovremennaya konczepcziya, prioritety` i mekhanizmy` realizaczii / ed. Meldakhanova M.K. - Almaty: EI SC MES RK.

19. Bureau of National Statistics, 2021 [updated October 19, 2021; cited October 30, 2021]. Available: http://www.stat.gov.kz

20. National SDG reporting platform Bureau for National Statistics, 2021 [updated October 19, 2021; cited October 30, 2021]. Available: https://kazstat. github.io/sdg-site-kazstat/ru/
21. Information and analytical system "Taldau" Bureau of National Statistics, 2021 [updated October 19, 2021; cited October 30, 2021]. Available: [https:// taldau.stat.gov.kz/]

22. Serebryakova, N.A., Volkova, S.A., \& Volkova, T.A. (2019). Human integralassessment methodology capital of the region. Vestnik VGUIT [Proceedings of VSUET], 81(3), 375-380.

23. Zubarevich, N.V. (2003). [Social Development of Russian Regions: Problems and Trends in the Transition Period]. Soczial noe razvitie regionov Rossii: problemy` i tendenczii perekhodnogo perioda, Moscow, Editorial URSS.

24. Golenkova, Z.T., Kosharnaya, G.B., \& Kosharnyy, V.P. (2018). Influence of Education on Improved Competitiveness of Employees in the Labour Market. Integratsiya obrazovaniya $=$ Integration of Education. 22(2):262-273. DOI: 10.15507/19919468.091.022.201802.262-273

25. Nyussupova, G., Aidarkhanova, G., \& Young, S. S. (2021). The impact of the transformation of the economy of the Republic of Kazakhstan on the reproduction of human capital: socio-economic aspect. Studies of the Industrial Geography Commission of the Polish Geographical Society, 35(2), 38-52.

26. [Decree of the President of the Republic of Kazakhstan "On some issues of the administrativeterritorial structure of the Republic of Kazakhstan"]. «Qazaqstan Respýblıkasynyń ákimshilik-aýmaqtyq qurylysynyń keıbir máseleleri týraly» Qazaqstan Respýblıkasy Prezıdentiniń jarlyǵy. dated June 19, 2018 No. 702. (In Kaz).

27. World Development Report (2019). The Changing Nature of Work, World Bank.

28. Mincer, J. and Polachek, S. (1974). Family investments in human capital: Earnings of women. Journal of Political Economy, 82, 76-108.

29. Kraay, A. (2018). Methodology for a World Bank Human Capital Index. Policy Research Working Paper, 8593. 


\section{Information about the authors}

* Gulnara N. Nyussupova - Doctor of Geographic Sciences, professor, Head of the Department of Geography, Land Management and Cadastre, Al-Farabi Kazakh National University, Kazakhstan, e-mail: gulnara.nyusupova@kaznu. kz, ORCID ID: https://orcid.org/0000-0001-5294-2671

Gaukhar B. Aidarkhanova - PhD student, lecturer of the Department of Geography, Land Management an d Cadastre, Al-Farabi Kazakh National University, Kazakhstan, e-mail: gauhar_222@mail.ru, ORCID ID: https://orcid. org/0000-0001-7280-7071

Aigul A. Tokbergenova - Candidate of Geographic Sciences, Docent, Deputy Head of Department on academic affairs and educational work, Al-Farabi Kazakh National University, Kazakhstan, e-mail: aigul.tokbergenova@, kaznu.kz, ORCID ID: https://orcid.org/0000-0002-1934-5063

\section{Авторлар туралы мәліметтер}

* Нүсіпова Г.Н. - г г.ғ.д., профессор, география, жерге орналастыру және кадастр кафедрасының меңгерушсі, әл-Фараби атындағы Қазақ Ұлттық университеті, Қазақстан. e-mail: gulnara.nyusupova@,kaznu.kz, ORCID ID: https://orcid.org/0000-0001-5294-2671

Айдарханова Г.Б. - докторант, география, жерге орналастыру және кадастр кафедрасының оқытушысы, әлФараби атындағы Қазақ Ұлттық университеті, Қазақстан . e-mail: gauhar_222@mail.ru, ORCID ID: https://orcid. org/0000-0001-7280-7071

Тоқбергенова А.А. - г.ғ.к., доцент, кафедра меңгерушісінің оқу-әдістемелік және тәрбие жұмысы бойынша орынбасары, әл-Фараби атындағы Қазақ Ұлттық университеті, Қазақстан, e-mail: aigul.tokbergenova@kaznu. kz, ORCID ID: https://orcid.org/0000-0002-1934-5063

\section{Сведения об авторах}

* Нюсупова Г.Н. - Д. г. н., профессор, заведующая кафедрой географии, землеустройства и кадастра, Казахский национальный университет им. аль-Фараби, Казахстан, е-mail: gulnara.nyusupova@,kaznu.kz, ORCID ID: https://orcid.org/0000-0001-5294-2671

Айдарханова Г.Б. - докторант, преподаватель кафедры географии, землеустройства и кадастра, Казахский национальный университет им. аль-Фараби, Казахстан, е-mail: gauhar 222@,mail.ru, ORCID ID: https://orcid. org/0000-0001-7280-7071

Токбергенова А.А. - к. г. Н., доцент, заместитель заведующей кафедрой по учебно-методической и воспитательной работе, Казахский национальный университет им. аль-Фараби, Казахстан, е-mail: aigul. tokbergenova@,kaznu.kz, ORCID ID: https://orcid.org/0000-0002-1934-5063 